\title{
Factions, Variety, Diversity, Multiplicity: Representing Early Christian Differences for the 21st Century
}

\section{Citation}

King, Karen L. "Factions, variety, diversity, multiplicity: representing early Christian differences for the 21st century." Method \& Theory In The Study Of Religion 23, no. 3-4 (2011): 216-237.

\section{Published Version}

doi:10.1163/157006811X608368

\section{Permanent link}

http://nrs.harvard.edu/urn-3:HUL.InstRepos:10955120

\section{Terms of Use}

This article was downloaded from Harvard University's DASH repository, and is made available under the terms and conditions applicable to Open Access Policy Articles, as set forth at http:// nrs.harvard.edu/urn-3:HUL.InstRepos:dash.current.terms-of-use\#OAP

\section{Share Your Story}

The Harvard community has made this article openly available.

Please share how this access benefits you. Submit a story.

Accessibility 
Method and Theory in the Study of Religion 23 (2011), 217-239.

\section{Factions, Variety, Diversity, Multiplicity: Representing Early \\ Christian Differences for the $21^{\text {st }}$ Century Karen L. King \\ The Divinity School, Harvard University}

It now a recognized commonplace in the field of ancient Christian historiography to speak of "the diversity of early Christianity" and to characterize that diversity in terms of "varieties" or even multiple "Christianities." This nomenclature most frequently refers to differentiated types, whether represented as discrete social groups or distinctive theological perspectives, systems, or factions. Scholars speak readily of Pauline or Johannine Christianity, Jewish Christianity and Gnosticism, and debate the precise contours of such groups, their practices, beliefs, and histories.

The relative equanimity with which such characterizations are so widely embraced among academic scholars of otherwise quite different ideological persuasions and theological commitments may at first seem surprising. But closer inspection shows that scholars mean very different things and have quite different aims in view when they use this language. Although the general banner under which all this labor occurs is largely that of improving the accuracy of the historical narrative and remedying some of its gross partialities—and indeed historical-critical scholarship has achieved much toward these ends-, the appearance that this work is "disinterested scholarship" (objectivity 
being no longer a plausible claim) obscures how the varied attempts to represent early Christian differences serve a variety of different contemporary social-political ends, such as devising new ways to set normative boundaries of tolerable difference, promoting ecumenism, negotiating the tensions and possibilities of religious pluralism, resisting exclusivist (“intolerant") truth claims, or engaging in multicultural identity politics. For those who hold that the early church properly provides a model for contemporary Christianity, much can be at stake in how ancient difference is represented (see Alexeev et al 2008). For others, telling the story of Christianity differently can offer opportunities for extending or critiquing Christianity's impact on contemporary social and political life, or, perhaps, for opening up space to imagine better social arrangements (see Mack 2001: 197-199).

The shared language of "diversity of early Christianity" is thus not about one thing, but covers a wide variety of discrete, overlapping, or incongruous aims, methods, theoretical orientations, and institutional fields. Indeed, the terminology of Christian difference is itself more varied and less precise than it might appear. While the terms, "difference, diversity, variety, multiplicity" can be used interchangeably as synonyms, in contemporary discourse they can carry very different valences. "Difference" can connote separation, opposition or inherent incompatibility; "variety" is sometimes more neutral, a term that applies equally well to breakfast cereal choices or "the spice of life"; while "multiplicity" often signals little more than "being more than one." "Diversity," however, frequently appears in a politics which applauds distinctiveness and individuality. Such was decidedly not the case in antiquity, where Christian talk about difference was dominated by the language of factionalism. 
Visible in this shift from "factions" to "varieties" are the issues at stake in how early Christian diversity is now represented. It is in this context that two of the issues troubling contemporary scholars can be understood: how to resolve issues of normativity in the face of multiplying differences and divisions given the breakdown of old strategies and methods; and how to imagine the history of early Christianity without reinscribing the canon, creed, master narrative, and discursive strategies of orthodoxy and heresy. It is largely in addressing these problems that new modes of representing difference in terms of "the variety, diversity, or multiplicity of early Christianity" can be located, and it is in this context that my own preferences and interests may be placed as well.

The extant literature indicates that early Christians formulated the issue of difference less in terms of "variety" or "diversity" than as a problem of factionalism. Already with Paul's First Letter to the Corinthians, difference is rhetorically represented this way, and Paul heavily deploys Greco-Roman political discourse of unity and concord to argue for accepting his position as the correct one (see Mitchell 1993: 65-183). So, too, early Christian polemics, such as those of Irenaeus and Tertullian, frequently contrasted the unity and uniformity of their pure Church with the divisions and diversity of heretics whose teaching they claimed had been fomented by Satan (see King 2003: 3138). For centuries, a set of enduring tools and strategies - including especially canon, creed, hierarchical male authority, a discourse of orthodoxy and heresy, ${ }^{1}$ as well as a

\footnotetext{
1"Orthodoxy" and "heresy" are terms of normative evaluation belonging to particular discourses of power and identity. Their use signals a rhetoric aimed at defining boundaries of self and other within a group. Such processes involve exertions of power that exclude and silence, even as they articulate the meaning of self in the face of
} 
"otherness." The power relations implied in discourses of orthodoxy and heresy are firmly embedded in struggles over who gets to say what "truth" is, and they have their discursive setting in on-going processes of Christian self-definition and identity formation. In King 2003: 20-38, as a heuristic device for demonstrating the intersection of certain ancient and modern discourses of Christian identity, I listed some elements of ancient Christian discourse of orthodoxy and heresy, noting that this harmonized summary does not do justice to the specificity or the complexity of the polemicists' varied arguments, nor is it necessarily a complete list. In this discourse, a limited number of strategies are deployed, most if not all to be found variously disposed in other boundary-setting, identity-forming activities among Jews, Greeks, Romans, and others in antiquity, as well as in Christian literature before the use of the actual term "heresy" per se. These include prominently: limiting who was allowed to interpret Scripture, to say what it really meant; establishing a rule of faith to regulate interpretation; attacking the character of one's opponents; calling themselves true Christians and their opponents heretics (or waterless clouds, etc.); arguing that heretics lacked the truth (whether by the absence of some positive moral or theological trait or the presence of error) and their own views are theologically superior; devising competing genealogies, e.g., from Christ (through apostolic succession which equates the true Church with a hierarchical order of male authority, said to stem from Jesus through the twelve male apostles) or from Satan (through Simon Magus)—-here origin is meant show essence and character; contrasting the unity of the true Church with the divisiveness of heretics (unity implied uniformity while difference implied divisiveness.); insisting that adherence to the authority of the established leadership of the one institutional Church constituted orthodoxy; doctrinal 
master narrative of an original Christian unity disturbed by heretical schism—served as indispensible tools in the arsenal of mediating the continuing controversies over which Christianity is true and who gets to say (see Le Boulluec 1985; King 2003: Lieu 2004). Yet powerful as these tools proved to be, and whatever limited effects they may have achieved in moderating differences at some times and places, they have been manifestly ineffective in resolving substantive differences and unifying Christians more broadly, and may indeed at times have been counterproductive by sharpening boundaries that contributed to more or less permanent divisions (see Lampe 2003: 398-408; Thomassen 2004; King 2008a). The failure of such tools became increasingly apparent in Europe at a time when the contemporary divisions among Christians had not only become increasingly stark after the Protestant Reformation, but increasingly problematic in the face of religious wars and other strife.

The rise of historical criticism only further troubled the situation. In trying to square the old master narrative of Christian origins with the new standards of historical objectivity, historians not only strained the facticity of many elements, they significantly challenged the assumptions and strategies of the discourse of orthodoxy and heresy. Recoveries of ancient manuscripts, such as those from near the Dead Sea or Nag Hammadi in Egypt, only exacerbated the problem by multiplying differences at the same time that the traditional repertoire for dealing with differences was being seriously challenged. Over the last decades, the frameworks of phenomenology and historical

variation constituted social deviation (schism); alleging that heresy is produced by outside contamination of an originally pure faith (e.g. by the importation of Greek philosophy); asserting that truth is chronologically prior to heresy. 
criticism themselves have faced serious challenges that are only gradually being felt from post-structuralist, post-modern, and post-colonial theorizing. Religious pluralism, political democracy, and feminism have destabilized the claims of canon, creed, and male hierarchies.

Nonetheless, the ancient rhetoric of unity and concord, with its accompanying disparagement of difference as divisive factionalism, continues to serve as the operative framework for many historians - and even critics of normative identity projects ("orthodoxies") can fall into oppositional strategies that merely reproduce the terms of the problem as defined by ancient polemics. ${ }^{2}$ Arguably, the function of all such heterodox nomenclatures is to effect the marginalization or omission of that which they claim to name, and thereby to establish the contours of what is normative or orthodox, but a binary structure means that the rhetoric can cut two ways. By framing early Christian variety within a binary structure (e.g., orthodox/heretical, normative/heterodox, mainstream/marginal), the possibility arises of reversing the evaluative weight of the terms. So, for example, when Gnosticism is defined and positioned over against (some version of "true") Christianity, it can serve variously not only to reinforce notions of orthodoxy but also to critique dogmatic claims and institutional structures. Discursively cast from its inception in a binary frame of orthodoxy and heresy, Gnosticism was well positioned to turn the critical gaze of the heterodox Other back on its detractors. Thus, if

\footnotetext{
${ }^{2}$ This problem is notably manifest in the reluctance to give up the terminology of "orthodoxy" or "Gnosticism," or in the difficulties of developing adequate alternative categories even among those who eschew "orthodoxy and heresy" as proper terms for historical analysis.
} 
Gnosticism was decried for allowing women to serve as leaders, it could be used to critique patriarchal structures of church authority. If Gnosticism was denounced for the multiplicity of its views, it could be aimed against intolerant and narrow dogmatism. If Gnosticism was criticized for its negative views of the body and creation, it could nonetheless be touted as an individualistic spiritual alternative in an age of materialism and coercive conformity. In the end, however, all such oppositional deployments on whatever side of the issue maintain the fundamental structure of orthodoxy and heresy discourse, in which each term requires the other to establish its content, boundaries, and indeed its intelligibility. Intelligibility is of course laudable, but it is requires complementary articulation of who is (dis)served, to what ends, and so forth. To a large degree, the usage of orthodoxy and heresy discourse uncritically reproduces standard typological definitions, e.g., of Gnosticism as radical anti-cosmic dualism, body-hating asceticism, especially in denouncing sexuality and sexual reproduction, and impious interpretation of Scripture (for attempts at correctives, see e.g., Williams 1996; King 2005, 2011).

In this context, let me note as a side comment that it may not be assumed automatically that anything "positive" said about such "heresies" automatically constitutes a criticism ("bashing") of "traditional Christianity." Such an assumption is rather a product of this bifurcating framework. Getting out of that way of thinking altogether is needed precisely in order to be able to think constructively as well as critically.

In representing early Christian diversity, the terms of "orthodoxy and heresy" are now generally rejected, either because of their unacceptable normative implications for 
"impartial" historiography or because they tend to cast the plural situation in an overly simplifying bifurcation (see Lieu 2004: 297). For some ends, especially promoting ecumenism, the language of "unity and diversity" more adequately frames the situation and defines the problem - how to talk about the unity of Christianity given the variety of (acceptable) forms of Christian expression both in antiquity and today, while yet setting limits to tolerable differences (see Dunn 2006: 1-8). Too narrow a focus on difference can obscure connections, similarities, and continuities, raising acutely the question of how to speak about the unity of Christianity in the face of such variety. While the problem can be particularly acute with regard to normative issues of biblical interpretation and authority (Johnston 1985: 5-15), it is a significant issue for historical representation as well (Thiessen 2008; Brakke 2010: 5-18).

Solutions like that offered by Adolf Harnack (1957: esp. 54-56, 62-68,149; see King 2003: 55-70), positing a transhistorical "essence" that remained intact despite changing historical dress or development, were unsatisfactory to historians who conceptualized meaning as a function of context. A more historically rooted approach is to posit an original, common theological core that persisted despite diverse expressions, offering stability and consistency as the Christian mission adapted to new audiences and situations (e.g., Dunn 2006; see also Johnston 1985: 11-13; Matera 2007). One difficulty with this approach is apparent by the fact that no agreement has been reached in identifying what constitutes that "core," let alone in theorizing how anything could remain entirely stable and produce sameness and continuity not only throughout the diverse manifestations of antiquity, but across two millennia into the transnational pluralism of global Christianity. 
Another recognized difficulty lies in using typological methods to mask the reinscription of orthodoxy/heresy discourses. Phenomenological-typological classification is widely used to group early Christian literature into set types. Each type is generally established by grouping a set of material together based on a limited number of similar features, describing their common essential characteristics, and then differentiating the resultant type from other types derived by the same means. This kind of method produced what became more or less standard conventions to characterize early Christian diversity. Divisions into basic types, such as Jewish, Gentile, or Hellenistic Christianity, Apocalypticism, or early Catholicism (e.g., "universalizing" Christianity), sometimes contrasted with their "excesses" in Ebionism, Gnosticism (Sethianism, Valentinianism, Marcionism), or Montanism pervade discussions of the varieties of early Christianity (see e.g., Dunn 2006: 253-400). As the list suggests, these types can be resolved back into two groupings that reinscribe the categories of orthodoxy and heresy, albeit often without using such normative terms, but rather talking about "mainstream" or "proto-orthodox" Christianity in contrast to "marginal" or "lost" Christianities (see King 2008b: 149-155). In this way, the terms to describe early Christian diversity often fit all too neatly into the old bifurcating frame, whether the specific terms "orthodoxy and heresy" are used or not, even if there is no apparent interest in setting normative boundaries. Such divisions have increasingly come under criticism.

As Brakke points out so insightfully, such divisions into fixed types of early Christianity can function to script the narrative of church history as a battle or horse race between those who won and those who lost (Brakke 2010: 7-8). Yet while that framework helpfully allows normative social-historical or theological discussion about 
the strengths and inadequacies of the players, it can also mask a naturalizing reinscription of the superiority of a predetermined orthodoxy, albeit now represented as a fact of history rather than the working of God (as Gamaliel puts it in Acts 5:38). Historians like Brakke argue that "if we are to appreciate truly the diversity of early Christianity and not dissolve that diversity into a soup of hybridity, we still need to make distinctions among forms of Christian life. ... Our goal should be to see neither how a single Christianity expressed itself in diverse ways, nor how one group of Christians emerged as the winner in a struggle, but how multiple Christian identities and communities were continually created and transformed" (Brakke 2010: 15). He shows what is required to put distinctive social groups on a strong historical footing when he delineates the literary remains and historical evidence of an early Christian group ("a school of thought") called "Gnostics," not on the basis of typological abstraction but by sifting through the reports of polemicists, identifying their literature, myth, and rituals (Brakke 2010: 29-89). ${ }^{3}$ What I applaud most, however, is his quite accurate historical observation that "No forms of Christianity that existed in the second and third centuries have survived intact today; rather, they have all contributed, in greater and lesser ways, to the ongoing development of Christianities" (Brakke 2010: 136). I would certainly include the first century as well. The crucial point for representing early Christian diversity, however, is that both historical understanding of the dynamics of Christianity in antiquity and the resources for

\footnotetext{
${ }^{3}$ He builds on the work especially of Layton (1995) who also starts with categories given by the ancient texts, and works from there to a characterization of the materials of classical Gnosticism that is very close to that of Sethian Gnosticism established by Schenke $(1974 ; 1981)$ on a typological basis.
} 
contemporary reflection are impoverished by supposing that only certain types of ancient Christians or certain groups of Christians contributed to the on-going practices that constitute Christian tradition. It is not that the orthodox won and the heretics lost (as their own rhetoric declares), but that what variously constitutes Christianity is always in the on-going process of formation, deformation, and reformation; constituted of the plural voices, practices, and possibilities of tradition past and present.

Typological classification is of course not itself the problem. It has, for example, the advantage of limiting the numerous differences among early Christian literature to a manageable number of basic types. Serious problems arise, however, when the constructed character of such categories is forgotten, such that the limits of selectivity are not appreciated and the resulting categories become improperly reified as homogenous groups rather than understood as tools designed to do certain kinds of intellectual work. When regularities are then turned into sharp social boundaries, the characterization of a type can become transformed into the characteristics of a posited group. And since typological method uses comparison differentially (that is, it tends to emphasize similarities within a type but emphasize differences among types), it gives the impression of a well-bounded homogeneity within each imagined group and creates overly sharp external distinctions between type-groups. Internal homogeneity thus arises not from the surviving evidence (which invariably testifies to many different kinds of variety within groups) but from the method itself, given that such categorization requires that some characteristics have to be selected as essential, while others are ignored or minimized.

Typology has also been used to address problems for which it is not suited methodologically. I think here of the way in which the over-determined category of 
Jewish Christianity is recognized to be manifestly confused, not only because it serves disparate ends, but insofar as it bundles together what are quite distinct literary phenomena that point toward different histories, types of social formation, practices, and theological views (including some groups invented by Christian polemicists [see Taylor 1990: esp. 326-327]). For example, in attempts to clarify the so-called "parting of the ways" between Judaism and Christianity, ${ }^{4}$ the term "Jewish Christians" functions to mark not only the "Jewish origins of Christianity," but also to account for widely varied reports of overlapping practices, such as synagogue attendance, ritual practices, or biblical interpretation. While it is clear that ancient Christians defined themselves in a wide variety of ways with regard to (other) Jews and Judaism, and indeed that they defined "Judaism" in various ways so as to make it into a entity usable for their own selfdefinition and boundary setting (see esp. Lieu 2002: 117-134; 2004: 290-292; King 2005: 38-47; 2008b: 161-172), to reduce such attempts into reified groups (Christians, Jews, Jewish Christians) is now widely recognized as highly problematic. Not only is the constructed character and rhetorical utility of all three of these categories obscured by naturalizing them as distinct social groups, but the complexity of social-intellectual strategies and the real practices and problematics on the ground can become oversimplified. It would be more accurate to speak of a variety of Christian positionalities than a single monolithic entity. Or rather I should say, than three

\footnotetext{
${ }^{4}$ The issue in much recent discussion has been how, when, and where did Christians and Jews "part ways, or whether that is even the correct way to put the question of contact and (reciprocal) projects of self-definition (see e.g., Lieu 2002:11-29; Boyarin 2006; Becker and Reed 2003).
} 
monolithic entities, since the frequent division of earliest Christianity into Jewish Christianity (too much, too positive a relation to Judaism), Gnosticism (too little, too negative), and proto-orthodox Christianity (just right) also naturalizes the "proper" (i.e., historically dominant) solution to this problem — and it does so definitionally rather than by engaging the much more messy perspectives of the literature.

While historical analysis usefully remedies the ahistorical deficiency of typological classification by addressing diachronic change, it, too, frequently has employed methodological assumptions, logics, and practices that can also turn the manifest differences of early Christian literature into a set of more or less theologically uniform and socially separate, well-bounded groups, each with its own origin and history of development, such Pauline or Thomas Christianity, the school of Matthew, the Johannine or Q community, and so forth. Analytic categories and constructs can be reified into historical entities and agents by "sliding from the model of reality to the reality of the model," as Pierre Bourdieu (1990: 37) puts it. Reification can also occur by turning literary elements into historically actual agents, for example, if the inscribed author, narrator, or readers are uncritically read as transparent pointers toward the real author and readers. Scholars are, however, now widely aware of these problems and use literary methods to analyze how inscribed actors are constructed and to what ends. More critically, inscribed rhetorics itself now are understood as interventions in complex, dialogical situations that shift as a literary work is copied and distributed along networks.

In some cases, the social milieu itself has been considered to supply the impetus for literary and social generativity, not entirely unlike causes previously ascribed to metaphysical entities and essences (God, the Spirit of the Age, History or the Nation) or 
to Great Men (Jesus and Paul). The sociological turn to a kind of contextualism or methodological wholism could make social upheaval, anti-Roman sentiment, innerJewish conflict (reform), or other social, economic, or political factors and conditions appear to be sufficient to account for the kind of social experimentation, new stories, or ideological adjustments evidenced in Christian literature. While few would any longer make such bald claims, the tendency to treat social context as determinative (generative) of (univocal) meaning continues. Critics have made it clear, however, that while literature is produced by people whose activities, products, and social formations are shaped and constrained by social-economic-political conditions, no directly determinative relation exists such that a given social situation will mechanically produce a particular form of literature, style of social group, or single meaning.

To note that attempts to move beyond orthodoxy and heresy are impeded by categories and methods that do not entirely escape their thrall cannot, however, amount to an eschewal of the important work being done on the social and intellectual history of early Christianity, nor to be a rejection of normative social, ethical, or theological projects per se. Scholarship over the last decades has helpfully shown that in some cases we have been writing histories that never happened by relying on methods that mistake rhetoric for reality, improperly reify analytic categories, or construct untenably harmonious wholes from individual texts or groupings of texts. We now recognize that the ancient materials are partial both in terms of their partisan commitments, as well as their gaps and omissions, and these insights are beginning to change the historiography of ancient Christianity. 
Important shifts have occurred by rethinking what the extant evidence is evidence of. The New Testament synoptic gospels, for example, are now recognized not as fundamentally reliable chronicles of the actual events, but as storying of generically varied sayings and deeds that leave traces of their own literary production, social and theological (ideological) interests, and rhetorical strategies. Ehrman (1993) has shown that ancient scribes "corrected" scripture to address ambiguities or exclude unwelcome views - a practice also pursued in modern times, for example as Brooten has shown, by transforming the woman apostle Junia into a man ("Junias" in Romans 16:7 RSV; Brooten 1977; see also Epp 2005). Ancient Christian claims to universality are now read in light of how early Christian literature evinces tensions over the roles of women and slaves, between Jews and Gentiles, and along class lines. Denise Buell (2005; esp. 138165) has argued persuasively that Christian "universalism" was constructed by contrasting it to Jewish particularism and through exclusion of non-Christians. Such insights lead scholars not to try to reconcile diverse accounts into a single uniform and non-contradictory history or theology nor to classify differences into well-bounded entities, but to grasp differences as keys to the dynamics of Christian social and theological practices.

Appreciating the partisan interests of the ancient sources also has led historians to take more care to avoid misunderstanding what the evidence actually evinces. Rather than positing groups that never existed by reinscribing the rhetoric of ancient Christian polemicists, we can now better perceive where they invented sectarian nomenclature, groups and divisions, or even fashioned artificial "unities." Justin Martyr, for example, explicitly states that even though people whom he considers to be heretics and 
blasphemers call themselves Christians, his practice is to refer to them instead by the names of the teachers who ostensibly originated their "false" teachings and opinions (see Justin Martyr, Dialogue Against Trypho 35.4-6). Yet while it is clear that the dialogue's main locutor "Justin" intends his (fictional) interlocutor "Trypho" to separate true from false Christians, it is much less clear to modern scholars whether the Christians Justin is excluding actually formed groups distinguishable sociologically from other (to Justin "true") Christians or whether he is himself producing a separate nomenclature as a strategy to exclude them. As Judith Lieu points out, the "power of naming" can be an extremely effective strategy, but its polemical success is not a sufficient indicator of reality on the ground (Lieu 2004: 267-268). ${ }^{5}$ Irenaeus may have created the schism of Valentinus from "the Roman church" (see the discussion of Thomassen 2006: 420-422), and Epiphanius (Panarion I.35,3,5) surely invented from thin air a number of groups whose existence strains credibility—Stratiotics and Socratites! — to fill up the number of eighty heresies to correspond allegorically to the eighty concubines of Solomon. Similarly, Irenaeus' insistence upon the multitude of heretical groups, for example, fits

\footnotetext{
${ }^{5}$ Among the heretics named by Justin in the passage cited above (Marcionites, Valentinians, Basilidians, and Saturnilians), only literature penned by the Valentinians has survived, but even then in none of the trove of newly discovered literature from Nag Hammadi is "Valentinian" ever used as a self-designation. Indeed, when an "heretical" text, such as Testimony of Truth 56.1-5; 58.2-4, does mention Christians such as disciples of Valentinus or Simonians, it is clearly employing the same polemical strategy of naming opponents as Justin. In that case, however, the people who falsely call themselves "Christian" are said to include Christians who marry or are martyred.
} 
better his representation of orthodox Christians as uniform in belief and unified in social organization and ritual practice, in contrast to the interminable disagreements, schismatic divisions, and fabrications of the heretics.

This polemic not only multiplies types of "heresies," but the rhetoric of unity also works to obscure the differences within Irenaeus' "orthodox church" as well, differences that would not in any case fit a bifurcating schema of "orthodox" and "heretical." Rather the vantage point Irenaeus affords viewers is positioned so that some differences are spotlighted while others are obscured in shadows. Heretical as well as orthodox "unities" may have been created as well. Taylor suggests that patristic authors amalgamated various groups of Christians into "a kind of 'Ebionite' coalition" and invented other heretical groups by "transferring characteristics of known groups onto other groups in order to flesh out their heretical position" (Taylor 1990: 327). Such examples of cases where ancient polemicists invented groups or obscured differences to serve their polemical aims could readily be multiplied, and scholars have become increasingly aware of such dangers in describing the "varieties" of early Christianity, turning instead to analyze the rhetorical strategies of calls and claims to unity against the divisive divisions of their opponents.

It is now clear, too, that modern scholars have also produced additional groups that never existed by extrapolating from polemical arguments. For example, attempts to determine "the opponents" of Paul in Corinth, which led scholars to posit an astonishingly varied proliferation of separate factional groups, are now understood to be more the product of scholarly method than historical likelihood (see Mitchell 1993: esp. 302-303). Or again, when Ignatius rails against fellow Christians who in his opinion 
wrongly "Judaize" or believe that Jesus was not truly flesh, historians have pointed out that it is misleading to turn his polemics into well-defined types of Christianity (Jewish Christianity or Docetism) or reifications of distinct groups of opponents. Rather, as William Schoedel (1980: 30-44; see also Lieu 2004: 134-36) argues, it seems Ignatius himself may have exaggerated moderate differences into polarizing divisions as he advocated for unity under episcopal authority and sought to legitimize his willingness to die for God. Such examples could easily be multiplied.

Scholars have also begun to consider what the evidence does not supply evidence of, given not only the extremely fragmentary and selective character of the surviving artifacts, but also their partialities. Whose voices are heard? Who is missing? Building his argument in part upon an "argument from silence," Walther Bauer (1971), for example, suggested that the lack of information about Christianity in a specific area might not signal its absence but rather its "heretical" character. What or who, we now ask, might have been "disappeared" from the historical record? As with heretics, so too with women and slaves. Crafting a productive "hermeneutics of suspicion," Elisabeth Schüssler Fiorenza (1985) preeminently succeeded both in illuminating the presence, activities, and contributions of women to the formation of Christianity, and in exposing the partiality of "kyriarchal" sources. Many historians are looking now to find evidence for the presence of slaves and to investigate the fact that Christianity was formed in a slave-owning society (Glancy 2010:24-80; Brooten 2010).

Such approaches have begun to underscore the multiple perspectives and positionalities within Christian groups, not merely between sects or "types" of Christianity. Texts can be analyzed to hear not just the author's views, but the multi- 
voiced audience and the potentially multiple ways readers heard. We no longer expect, for example, to identify the single type of (heretical) "opponent" Paul is combating in Corinth, but try to listen to the broad range of views he is dealing with in what was an economically and socially diverse group (of Gentiles, Jews?, slaves and slave owners, relatively wealthy members and the very poor, and unveiled women prophets, among others). Paul is not ousting a few heretics, but trying to provide guidance and strategies for some kind of basis for unity before things fall apart entirely. Scholars now recognize that Paul's voice is one among many, and indeed that he may not have won the day in first century CE Corinth.

This methodological perspective allows the social and theological experimentation and creativity of Christians to appear alongside their cranky contentions and serious disputes. Seeing them, however, requires giving up the notion of a single core Christianity at some (mythological) moment of origination and not everyone is willing to do that. One of the disadvantages — or advantages depending upon one's point of view— to reinscribing contemporary instantiations of orthodoxy-heresy discourse or deploying typological modes of categorization is that they largely restrict the kinds of difference/diversity that are considered to be consequential for describing theological/ideological differences or delimiting distinct social groups. While mapping such differences is offering real insight into early Christian diversity, limiting the kinds of difference that count to defining the distinct characteristics of a theological position or individual social group in isolation can work to contain many of the disruptive challenges and insights that consideration of a wider range of differences potentially offers. 
Enlarging our framework can open up to analysis a variety of analytically distinct but mutually implicated kinds of difference that are operating, such as: the multivalent character of language; the dialogical character of communication; (shifts in) materialsocial contexts, reader positions, and power relations; the kinds of social and intellectual work writings are said to be doing; theological, ideological, and rhetorical assumptions, aims, and strategies; problems, ideas, and narrative accounts. Each of these conceptualizations of difference comes laden with assumptions and points toward certain methods or theoretical foundations, which are themselves topics of serious debate among philosophers, literary theorists, sociologists and anthropologists who frame the issues somewhat differently. As Robert Berkhofer (1995: 233) notes, for example, with regard to controversies between contextualists and textualists over the social versus textual construction of reality in historiography, under contestation are "basic approaches to or models of human psychology and behavior, society and culture, explanation and epistemology, and theories of language and ontology" (1995: 233; see also Chartier 1997; Clark 2004; Cameron and Miller 2004). Scholars of early Christianity draw variously upon these fields, the need for a clearer articulation of such contestations over basic theoretical positions has been called for (see Stowers 2004).

My own preferences and interests have to date most directly concerned what previously unknown Christian texts discovered in Egypt over the last century might bring to the discussion, both in offering fuller and therefore more adequate accounts of ancient historical situations and in opening up for critical and constructive reflection the diverse ways in which ancient Christians were thinking about certain problems. The two are linked in the presupposition that a more accurate and complex history can offer more 
adequate resources to think with in addressing the complexities of our own $21^{\text {st }}$ century. Manuscripts, such as the Berlin Codex, the Nag Hammadi Codices, and the Tchacos Codex, add many new voices and perspectives that potentially can significantly complexify our portraits of early Christians generally. For this purpose, differences are considered neither inherently good nor problematic, but a fact of social life in all its vitality. One approach, among others, to getting at the dynamics of early Christians' activities, rather than contain such differences statically through typological definitions and reified histories, would be to analyze the multifarious, fluid, and often contradictory practices in which Christians engaged in terms of the desires they had, the diverse problems they were trying to address, and the complex and divergent answers they forged at different times, places, under varied conditions, and from multiple social and intellectual positionalities. Historical reconstructions that represent well the instabilities, contradictions, and porousness of practical social life allow us better to see Christianity more and more as a dynamic movement with social traction, critical interests, theological imagination, and ethical commitments. In order to trouble containment strategies and expand consideration of a wider variety of differences, thinking about alternative frameworks to identify, organize, and interpret differences for ends other than reinscribing normativities is necessary.

My approach operates under several assumptions. I regard historiography as a site for enlarging one's imaginative universe and complexifying ethical and theological reflection. Attractive as the fantasy of pure objectivity and moral transcendence is, and as much as we mortals might desire fixed and unchanging truth(s), history can supply neither. Historiography cannot resolve issues of normativity by positing the past as the 
repository of fixed (naturalized) givens. Rather, "[t]he problem facing historians," as de Certeau writes, is "the possibility of acceding to the speech of the other.... What can we apprehend from the discourse of an absent being? How can we interpret documents bound to an insurmountable death, that is to say, to another period of time, and to an 'ineffable' experience always approached from an outside evaluation?' (de Certeau 1988: 244). I personally feel no sense of loss for the demise of impersonal objectivity because I find it hard to see it as other than an authoritarian masking of the refusal to come to terms with grief, uncertainty, and injustice - a refusal that is sometimes frightened, sometimes vicious, often well-meaning and usually passionate. But if loss, change, and difference are not acknowledged as fundamental to human life and sociability, much has to be ignored, marginalized, covered up, or silenced. And we will surely cover-up, deceive, ignore, or refuse to speak, not only because no account can be totalizing, given our mortal incapacity to grasp or represent totality, but because self-deception and partiality, like fantasy and imagination, are human necessities for action, psychological stability, creativity, and hope. The practical project, therefore, cannot be to expose all deceit, imaginaries, or reifications once and for all, any more than to establish truth once and for all. Rather historiography is a modestly particular, disciplined mode of engaging with what is at hand, to aid in acting as best we can in our manifestly limited ways against what does harm, constrains human flourishing, and foments violence.

To this end, my hope is that hearing alternative voices and stories may further the maturing of moral imagination and practice. As Michael Jackson writes: "As with other forms of labour, storytelling is a modality of working with others to transform what is given, or what simply befalls us, into forms of life, experience, and meaning that are 
collectively viable. ... Unlike polemic, which cultivates a disinterested, objective, abstract, and authoritative view from afar, stories are a form of 'situated thinking' that brings philosophy down to earth, working within the everyday lifeworld of human struggle, encompassing a plurality of perspectives, in order to gain an enlarged view of human experience. ... Stories reconcile us to this variousness, rather than seek to transcend or condemn it" (Jackson 2006: 252, 253). When the "diversity of early Christianity" has become comfortable, it might be just the time to ask how we have managed to domesticate the salutary capacity of our differences to disturb complacencies, expose unseen complexities, or feed the possibilities of imaginative vision, and to wonder if we have whittled unsettling indeterminacies and provocations into convenient and comfortable tools that obfuscate or authorize rather than illumine or heal. It is here that properly historical methods can impose a profitable discipline upon the imagination that, at its best, grounds thinking and acting more firmly in grim and gracious reality, with all its unsettling truths, instabilities, and grief-laden limitations.

With these ends and assumptions, what kind of framework might be useful? In a journal titled "Method and Theory in the Study of Religion," one might reasonably expect discussion of the category of religion. While definition of the term is hotly debated, I number among those who see the term (and the field) not as naming a unique or essential entity, but as a constructed category with a history that has been refined in a variety of ways for many different uses (see McCutcheon 1997). This perspective makes it necessary to historicize and contextualize our own assumptions and what constitutes religion as a rubric for investigation, as well as craft a theoretical approach sufficiently open that it can take account of multiple roles and positionings of beliefs and practices 
vis-à-vis "gods" or "the sacred" and perceive shifts in them over time. ${ }^{6}$ In the case of Mediterranean antiquity, religion is not a distinct field but is imbricated in many fields of social-political-economic life, and indeed one of the things Christians are up to is redefining and shifting the position of worship of God(s) with regard to matters such as ethnicity, social status, sex/gender, political governance and more (eventually working to Christianize social as well as cosmic time and space (see e.g., Markus 1990). In this case, representing difference in terms of the dynamics of embodied practices requires a theory of religion adequate to its aims, one admittedly provisional and positional, that contrasts sharply with notions that regard religion as a singular phenomenon (albeit with diverse cultural-historical expressions) and/or that regard religions as fixed, static, ahistorical entities, ideologically homogeneous and internally harmonious, properly uncontested. Rather what are frequently referred to as "religions" in antiquity can be thought of as multiform, plurivocal, unstable bundles of diverse and shifting practices, variously formed and formulated, that shape and are shaped by individuals and groups, with varying intersections of social, political, and economic life forms (such that at times a "religion" may appear as distinct, while in other times and places it is indistinguishable as a separate/able field), changing and varied over time and place (e.g., historically and

\footnotetext{
${ }^{6}$ For religion scholars interested primarily in the current debates about the legitimacy of religion departments in US institutions of higher education, it might be said that any of the current divisions into disciplines or fields of study are also constructs. The value of religion, or indeed any other such discipline or field, lies not in how intellectual labor is classified and divided as such, but whether such divisions aid in letting us see things worth knowing and worth thinking about.
} 
locally specific), always contested and fluctuating both internally and with regard to outside groups and ideological borders. One interesting thing then is to see what people who call themselves Christians are (variously) including or excluding as consequential. This definitional tool may not be useful with regard to other projects; indeed it should be regarded as provisional and positional, and its adequacy assessed in terms of its usefulness for the express purposes of seeing what comes into view in asking more broadly about "the diversity of early Christianities."

Such a theory would move analysis away from the categorical containment of differences, which represents them more or less as harmonious wholes made up of univocal, homogeneous, continuous, and mutually reflective relations among a set of group of actors, a well-bounded social situation, and a stable literary work, toward seeing them in embodied action as irregular, discontinuous interventions designed for practical, immediate and on the spot purposes. Here I would rely heavily on practice and performance theorists, such as Pierre Bourdieu (1990), Michel de Certeau (1988), Sherry Ortner (1996), Theodore Schatzki (2002), and Judith Butler (1999; 2004; 2006), whose work, while a project in progress, theorizes agency as a function of more or less scripted social and embodied performances in social-material-discursive contexts and networks that both enable and constrain. From this perspective, written documents could not be conceived as transparent repositories or windows onto social worlds but would appear as dialogically complex, socially embedded, linguistically formed interventions in those social worlds. One might then ask not only What do texts say? but What are they doing? What are the possible (shifting, multiple) effects of such material and linguistic interventions, anticipated or unanticipated? 
Disciplined historical imagination sets the literary remains of Christians within the larger framework of material conditions, social structures and discourses of the ancient Mediterranean world which work both to constrain and enable. It is their indeterminacy — "the lack of totalization of 'structure' itself" - that offers opportunities for resistance and transformation (Ortner 1996:18; see also Brown 2003; Butler 2004: 218; 2006:2-3). A theoretical framework that focuses upon identity formation, for example, can potentially offer insights into Christian history in terms of the dynamics of ongoing processes of construction, contestation, negotiation, and marginalization (see Lieu 2004; King 2008b). The point in any case would be not to foreclose which stories deserve to be told and which marginalized, but to increase the repertoire - and simultaneously sharpen critical as well as constructive reflections.

A particularly good approach to mapping differences in my view are studies which focus upon writing local histories of Christianity insofar as they are able to situate differences among early Christians within larger and more complex social landscapes, incorporating the much more extensive non-Christian remains of antiquity. An outstanding example here is Peter Lampe's examination of Christianity in Rome in the first two centuries (Lampe 2003: esp. 357-408; see also Thomassen 2004; Brakke 2010: 90-111). Utilizing archaeological remains, including data about burial sites and urban layout, alongside the available literary sources, he paints a properly fragmentary but lively portrait of Christians living and interacting with others in shared urban social space, while distinguishing themselves from outsiders by a number of markers. He can map these Roman Christians onto certain districts within the city and supply plausible suggestions about diverse ethnic, economic, and social educational status. He also lets 
the variety within Roman Christianity appear not as the breakdown of an originary unity, but as the function of discrete and overlapping practices, such as organization into localized house churches and leadership by elders. With only limited exceptions (notably Marcion), Christians combined topographical fractionation with extensive tolerance for theological multiplicity well into the late second century. Unity appeared in terms of cooperation and mutual recognition. Only with Bishop Victor (189-199 CE) does unity become a political aim requiring schism from other Christians, and Lampe ties this move to a monarchical episcopate to the need for greater coordination of internal economic affairs (care for the poor, donations, real estate) and external relations. His attention to multiple differences — economic, topographical, ethnic, educational status, and so onamong Christians is crucial in exposing "a breathtaking theological diversity" (2003: 381) without occluding the many ways that Christians cooperated and interacted with each other.

It is unfortunately the case that much of the extant early Christian literary evidence cannot be dated or located geographically with certainty (although some suggestions are arguably more plausible than others), thus significantly diminishing the usefulness of this sensible approach to mapping diverse practices onto complex social terrains. It is nonetheless salutary to ponder how few such local histories can actually be written, and how necessarily gapped and hypothetical are those that are. The fragmentary character of the evidence is good reason not to claim unwarranted certainty but to mark gaps, as well as ask who and what is missing, whose viewpoint appears, and what extant perspectives obscure as well as illuminate. 
In the past, I have argued that the first step is to analyze ancient Christians' strategies of self-definition in order to perceive the social and theological aims and effects of their discursive rhetoric. To what degree did the rhetoric of unity and uniformity not merely reflect ancient divisions in some transparent manner, but actually worked to produce them, to hide theological similarities, or to obscure the issues under debate and distort what was at stake? For example, by putting Irenaeus into conversation with The Secret Revelation of John rather than simply reproducing Irenaeus' perspective, it becomes possible to see where there was (perhaps mutual?) incomprehension, where they have different theological foci or where they side-step, ignore, or simply fail to be cognizant of the interests of the other. The results are surprising, both in the wide scope of the similarities they share and in locating their underlying differences in accounting theologically for injustice, sin, and salvation (see King 2008a).

These approaches require shifting from reinscriptions of ancient polemics, reifications of modern categories, and attempts to stabilize history and meaning, to a focus on the dynamics of social practices and on hearing multiple voices. Often, the "varieties of Christianity" are deployed precisely to categorize, and thereby to sequester, contain, and control the plethora of undomesticated things people imagine, say and do. But with their multi-voiced diversity, ambiguities, and transgressive interconnections, the ancient texts constantly resist and spill across the boundaries that attempt to fix their meanings. They impossibly complicate neat categories and test assumptions. It may be that attending to the problems they were facing may offer the possibility thinking afresh. And — this is my point really—challenging historians not merely to ask what the ancient teaching was, or even what multiple views were formulated, but what difference does it 
make that people tell certain stories in certain ways and not others? Then, for example, studies might address not what is the Christian doctrine of death and resurrection, or even what diverse views did early Christians hold and where did they agree or disagree, but what did — what does—it mean to think about life and death in such ways? What difference did it make — does it make — in how people face suffering and death, how Christians conceive(d) of God and their communities, how they narrate(d) the foundational stories of their "remembered" past? Or again, rather than ask what is the correct Christian teaching about sexuality or women's leadership roles, or even what were the diverse attitudes toward sex or the diverse roles of Christian women, studies might consider what are the implications for contemporary life of the diverse sex/gender practices and ideologies of early Christians regarding family, reproduction, and the body. We might ask how did Christian sexual morality and gender ideology (re)shape various notions and practices relating to the family, reproduction, and the body. What difference did it make — does it make — in how people love each other, whose love is valued and sanctioned, how the bodies of adults and children are cared for, managed, and disciplined, or how human flourishing is conceived and nurtured? Scholars might not only chart the facts of early Christian deaths at the hands of the Romans, or ask about the variety of responses Christians gave to persecution, but inquire about what it means that Christianity was shaped in and through these acts of torture and violence. What difference does it make how people survive oppression, how they tell their stories, and how those stories are institutionalized and repeatedly performed in ritual and story?

Will histories written locally, sensitive to absences as well as rhetorics, focused on hopes and problems be more true than reinscribed polemics or reified typologies? I 
think so. They, too, will be partial and positional, yet hopefully, helpfully marked as provisional, with attempts at self-reflexive discussion of theoretical assumptions, methodological aims, and contemporary ends, and taking care not to claim unwarranted authority and truth for our selective and imaginative readings. Then one need never say no to a story, a song, a poem that gives life, heartens, teaches, or consoles, and need never fail to call it true.

\section{REFERENCES}

Alexeev, Anatoly A., Christos Karakolis and Ulrich Luz with Karl-Wilhelm Niebuhr eds. (2008). Einheit der Kirche im Neuen Testament. Dritte europäische orthodoxwestliche Exegetenkonferenz in Sankt Petersburg 24.-31. August 2005.

Wissenschaftliche Untersuchungen zum Neuen Testament 218. Tübingen: Mohr Siebeck.

Bauer, Walther (1971). Orthodoxy and Heresy in Earliest Christianity. $2^{\text {nd }}$ ed. Philadelphia: Fortress Press.

Becker, Adam H. and Annette Yoshiko Reed eds. (2003). The Ways that Never Parted. Jews and Christians in Late Antiquity and the Early Middle Ages. Tübingen: Mohr Siebeck.

Berkhofer, Robert (1995). Beyond the Great Story: History as Text and Discourse. Cambridge: Harvard University Press.

Bourdieu, Pierre (1990). The Logic of Practice. Stanford: Stanford University Press.

(1991) Language and Symbolic Power. John B. Thompson (ed. and intro.). Cambridge, MA: Harvard University Press. 
Boyarin, Daniel (2006). Border Lines: The Partition of Judaeo-Christianity.

Divinations: Rereading Late Antique Religion. Philadelphia, PA: University of Pennsylvania Press.

Brakke, David (2010). The Gnostics. Myth, Ritual, and Diversity in Early Christianity. Cambridge, MA: Harvard University Press.

Brooten, Bernadette J. (1977). "Junia ... Outstanding among the Apostles" (Romans 16:7). In Women Priests. A Catholic Commentary on the Vatican Declaration. Leonard Swidler and Arlene Swidler (eds.). New York: Paulist Press. Pp. 141144. ed. (2010) Beyond Slavery: Overcoming its Religious and Sexual Legacy. New York: Palgrave Macmillan, 2010.

Brown, Gavin (2003). “Theorizing Ritual as Performance: Explorations of Ritual Indeterminacy.” Journal of Ritual Studies 17.1, 3-18.

Buell, Denise K. (2005). Why this New Race? Ethnic Reasoning in Early Christianity. New York: Columbia University Press.

Butler, Judith (1999). Gender Trouble. Feminism and the Subversion of Identity. New York: Routledge.

(2004). Undoing Gender. New York: Routledge.

(2006). Bodies that Matter. On the Discursive Limits of Sex. New York: Routledge.

Cameron, Ron and Merrill P. Miller, ed. (2004). Redescribing Christian Origins. Symposium Series 28. Atlanta: Society of Biblical Literature. 
Chartier, Roger (1997). On the Edge of the Cliff: History, language, and Practices. Baltimore and London: Johns Hopkins University Press.

Clark, Elizabeth A. (2004). History, Theory, Text: Historians and the Linguistic Turn. Cambridge, MA: Harvard University Press.

de Certeau, Michel. (1988). The Writing of History. Tom Conley (trans.). New York: Columbia University Press.

Dunn, James D. G. (2006). Unity and Diversity in the New Testament. An Inquiry into the Character of Earliest Christianity. $3^{\text {rd }}$ ed. London: SCM Press.

Ehrman, Bart D. (1993). The Orthodox Corruption of Scripture: The effect of early Christological Controversies on the Text of the New Testament. New York: Oxford University Press.

Epp, Eldon Jay (2005). Junia. The First Woman Apostle. Minneapolis: Fortress Press. Glancy, Jennifer A. (2010). Corporal Knowledge. Early Christian Bodies. Oxford: Oxford University Press, 2010.

Harnack, Adolf (1957 reprint 1908). What is Christianity? New York: Harper Torchbooks.

Jackson, Michael (2006). The Politics of Storytelling: Violence, Transgression and Intersubjectivity. Copenhagen: Museum Tusculanum Press.

Johnston, Robert K. (1985). Introduction: Unity and Diversity in Evangelical Theology.” In The Use of the Bible in Theology/Evangelical Options. Robert K. Johnston (ed.). Atlanta: John Knox Press. Pp. 1-17.

Kelley, Nicole (2006). "Philosophy as Training for Death: Reading the Ancient Martyr Acts as Spiritual Exercises." Church History 75.4, 723-47. 
King, Karen L. (2003). What is Gnosticism? Cambridge, MA: Harvard University Press.

(2005). The Secret Revelation of John. Cambridge, MA: Harvard University Press.

- (2008a). Social and Theological Effects of Heresiological Discourse. In Heresy and Identity in Late Antiquity. Eduard Iricinschi and Holger M. Zellentin (eds.). Tübingen: Mohr Siebeck. Pp. 28-49.

- (2008b) Which Early Christianity? In The Oxford Handbook of Early Christian Studies. Susan Ashbrook Harvey and David Hunter (eds.). Oxford Handbooks in Religion and Theology. Oxford: Oxford University Press. Pp. 66-84.

Lampe, Peter (2003). From Paul to Valentinus. Christians at Rome in the First Two Centuries, Minneapolis: Fortress Press.

Layton, Bentley (1995). "Prolegomena to the Study of Ancient Gnosticism." In The Social World of the First Christians: Essays in Honor of Wayne A. Meeks. L. Michael White and O. Larry Yarbrough (eds). Minneapolis, MN: Fortress Press. Pp. 334-350.

Le Boulluec, Alain (1985). Le Notion d'hérésie dans la littérature grecque II -III siècles. Paris: Études augustiniennes.

Lieu, Judith (2004). Christian Identity in the Jewish and Graeco-Roman World. Oxford: Oxford University Press. (2002). Neither Jew nor Greek? Constructing Early Christianity. New York and London: T \& T Clark. 
Mack, Burton L. (2001). The Christian Myth: Origins, Logic, and Legacy. New York: Continuum.

Markus, Robert A. The End of Ancient Christianity. Cambridge: Cambridge University Press, 1990.

Matera, Frank. J. (2007). New Testament Theology: Exploring Diversity and Unity. Westminster John Knox Press.

McCutcheon, Russell T. (1997). Manufacturing Religion. The Discourse on Sui Generis Religion and the Politics of Nostalgia. Oxford: Oxford University Press. Mitchell, Margaret M. (1993) Paul and the Rhetoric of Reconciliation: An Exegetical Investigation of the Language and Composition of 1 Corinthians. Louisville, KY: Westminster John Knox Press.

Ortner, Sherry B. (1996). Making Gender: The Politics and Erotics of Culture. Boston: Beacon Press.

Schatzki. Theodore R. (2002). The Site of the Social: A Philosophical Account of the Constitution of Social Life and Change. University Park, PA: University of Pennsylvania Press.

Schenke, Hans-Martin (1981). The Phenomenon and Significance of Gnostic Sethianism. In The Rediscovery of Gnosticism: Proceedings of the International Conference on Gnosticism at Yale, New Haven, Connecticut, March 28-31, 1978. Volume 2 Sethian Gnosticism. Bentley Layton (ed.). Studies in the History of Religions 41. Leiden: E. J. Brill, 1981. Pp. 588-616.

(1974). Das sethianische System nach Nag-Hammadi-Handschriften. In Studia Coptica. Peter Nagel (ed.). Berlin: Akademie Verlag. Pp. 165-174. 
Schoedel, William R. (1980). Theological Norms and Social Perspectives in Ignatius of Antioch. In Jewish and Christian Self-Definition. The Shaping of Christianity in the Second and Third Centuries. E. P. Sanders (ed.). Philadelphia: Fortress Press. Pp. 30-56.

Schüssler Fiorenza, Elisabeth (1985). In Memory of Her. A Feminist Theological Reconstruction of Christian Origins. New York: Crossroad.

Skinner, Christopher W. (2009). John and Thomas: Gospels in Conflict? Johannine Characterization and the Thomas Question. Eugene, OR: Pickwick Publications. Smith, Jonathan Z. (1978). Map is Not Territory: Studies in the History of Religions. Stowers, Stanley K. (2004). "Mythmaking, Social Formation, and Varieties of Social Theory." In Redescribing Christian Origins. Ron Cameron and Merrill P. Miller (ed.). Symposium Series 28. Atlanta: Society of Biblical Literature. Pp. 489495.

Taylor, Joan E. (1990). The Phenomenon of Early Jewish-Christianity: Reality or Scholarly Invention? Vigiliae Christianae 44 (4): 313-334.

Theissen, Gerd (2008). “Kirche oder Sekte? Über Einheit und Konflikte im frühen Urchristentum.” In Einheit der Kirche im Neuen Testament. Dritte europäische orthodox-westliche Exegetenkonferenz in Sankt Petersburg 24.-31. August 2005. Anatoly A. Alexeev, Christos Karakolis and Ulrich Luz with Karl-Wilhelm Niebuhr (eds.). Wissenschaftliche Untersuchungen zum Neuen Testament 218. Tübingen: Mohr Siebeck. Pp. 81-101.

Thomassen, Einar (2004). “Orthodoxy and Heresy in Second-Century Rome.” Harvard Theological Review 97 (3): 241-56. 
(2006). The Spiritual Seed: The Church of the 'Valentinians.' Nag Hammadi and Manichean Studies 60. Leiden: Brill.

Williams, Michael A. (1996). Rethinking 'Gnosticism': An Argument for Dismantling a Dubious Category. Princeton, NJ: Princeton University Press. 